\title{
(C) OPEN ACCESS \\ Febrile headache and leg weakness as the initial symptoms of tickborne encephalitis
}

\author{
Pierrick Le Borgne, ${ }_{1}^{1}$ Claudia Brunhuber, ${ }^{2}$ Pascal Bilbault ${ }^{1}$
}

'Emergency Department, Hopitaux Universitaires de Strasbourg, Strasbourg, France ${ }^{2}$ Radiology, Ortenau Klinikum Offenburg-Gengenbach, Offenburg, Baden-Wurttemberg, Germany

\section{Correspondence to}

Dr Pierrick Le Borgne, pierrick med@yahoo.fr

\section{Accepted 8 June 2017}

To cite: Le Borgne $P$ Brunhuber C, Bilbault P. BMJ Case Rep Published Online First: [please include Day Month Year]. doi:10.1136/ bcr-2017-220841

\section{DESCRIPTION}

A 61-year-old woman presented to the emergency department (ED) with a 1-week fever associated with progressive headache. She also reported weakness and paraesthesias in both legs. In the ED, the patient had normal vital parameters and reported no other medical history. Clinical examination showed a slight neck stiffness; the rest of the examination was normal. Laboratory findings showed a mild inflammatory syndrome. The patient had a lumbar punction; the cerebrospinal fluid (CSF) showed moderate pleocytosis (140 leucocytes/ $\mu \mathrm{L}$ with a mononuclear cell dominance). After a normal CT scan, an MRI examination was performed (figures 1and 2). Several days later, intrathecal IgM and IgG antibodies came back positive.

Tickborne encephalitis virus (TBEV) is a flavivirus that is transmitted by Ixodes spp ticks in a vast area (from western Europe to Japan). TBEV is endemic in Europe where climatic conditions are suitable for its circulation. After an 8-day incubation period following the tick bite, frequently $(1 / 3)$ unnoted by patients, the disease is usually biphasic. Initially, fever, fatigue and headache are the unspecific symptoms. The clinical spectrum in the second stage ranges from meningitis to severe encephalitis or myelitis. Serodiagnosis of TBEV is mostly straightforward (TBEV-IgM and IgG in blood or CSF). ${ }^{1}$ This represents around 10000 cases every year; morbidity is age related (highest in adults). About one-third of patients will have long-lasting sequelae (cognitive dysfunction, postencephalitic syndrome). No

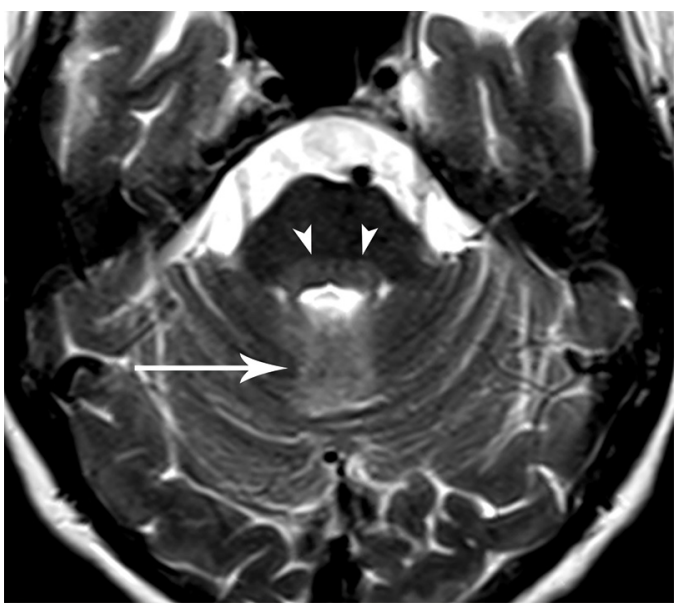

Figure 1 T2-weighted transverse MRI. Localised hyperintense band involving the tegmentum pontis (arrow heads) and the cerebellar vermis (arrow).

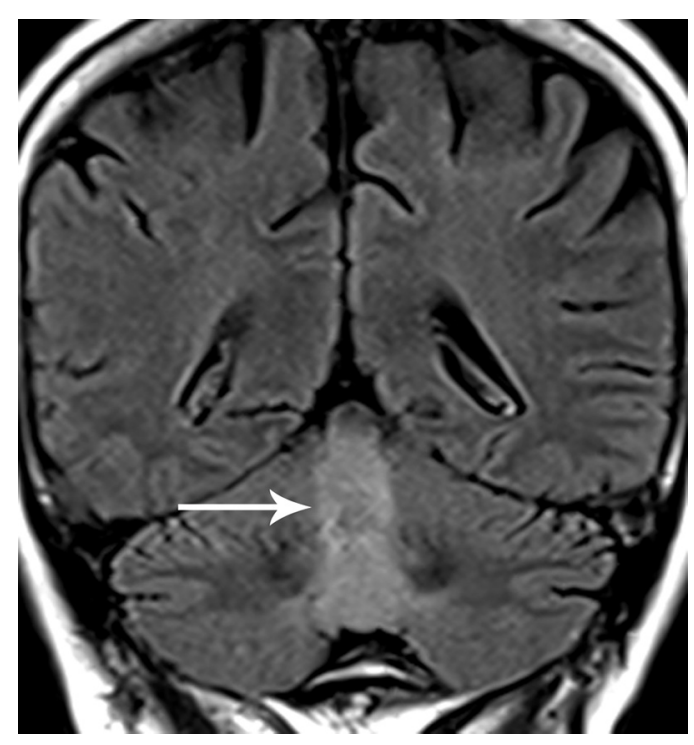

Figure 2 Coronal MRI, fluid attenuation inversion recovery sequence. Hyperintensity and swelling of the entire cerebellar vermis (arrow) with minimal involvement of the paravermis and sparing of the cerebellar hemispheres.

specific treatment exists, and active immunisation is the main preventive measure. ${ }^{2}$

Learning points

- Flavivirus is transmitted by Ixodes spp (from western Europe to the eastern coast of Japan).

- The serological diagnosis is usually straightforward.

- There is no specific treatment, and immunisation is the main preventive measure.

Contributors PLB and CB were responsible for the design, draft and writing of the article. PB wrote the article.

Competing interests None declared.

Patient consent Obtained.

Provenance and peer review Not commissioned; externally peer reviewed.

Open Access This is an Open Access article distributed in accordance with the Creative Commons Attribution Non Commercial (CC BY-NC 4.0) license, which permits others to distribute, remix, adapt, build upon this work non-commercially, and license their derivative works on different terms, provided the original work is properly cited and the use is non-commercial. See: http://creativecommons.org/licenses/by-nc/4.0/

(c) BMJ Publishing Group Ltd (unless otherwise stated in the text of the article) 2017. All rights reserved. No commercial use is permitted unless otherwise expressly granted. 


\section{Images in...}

\section{REFERENCES}

1 Lindquist L, Vapalahti O. Tick-borne encephalitis. Lancet 2008;371:1861-71.

2 Demicheli V, Debalini MG, Rivetti A. Vaccines for preventing tick-borne encephalitis. Cochrane Database Syst Rev 2009:CD000977.

Copyright 2017 BMJ Publishing Group. All rights reserved. For permission to reuse any of this content visit

http://group.bmj.com/group/rights-licensing/permissions.

BMJ Case Report Fellows may re-use this article for personal use and teaching without any further permission.

Become a Fellow of BMJ Case Reports today and you can:

- Submit as many cases as you like

- Enjoy fast sympathetic peer review and rapid publication of accepted articles

- Access all the published articles

Re-use any of the published material for personal use and teaching without further permission

For information on Institutional Fellowships contact consortiasales@bmjgroup.com

Visit casereports.bmj.com for more articles like this and to become a Fellow 